\title{
The Protection of Internally Displaced Children in Africa: A Doctrinal Analysis of Article 23(4) of the African Children's Charter
}

\author{
Romola Adeola* \\ University of Pretoria, South Africa \\ romola.adeola@gmail.com

\section{Benyam D Mezmur**} \\ University of the Western Cape, Cape Town, South Africa \\ bmezmur@uwc.ac.za
}

\begin{abstract}
This article considers the protection of, and assistance for, internally displaced children (IDCs) in Africa. Internal displacement has become one of Africa's most pressing human rights challenges. Over the last decade, millions of persons have been internally displaced on the continent by conflict, disaster and other causes. Children are one of the most affected categories of persons, given the implications of displacement for them. Article 23(4) of the African Charter on the Rights and Welfare of the Child incorporates specific protection for IDCs. This article examines the protection of IDCs in the context of this regional framework. It argues that, while article 23(4) requires that both refugee children and IDCs should be accorded the same protection from a rights-based perspective, it also requires that the protection of IDCs should be construed with reference to the Kampala Convention, which is the most recent applicable regional regime governing internal displacement.
\end{abstract}

\section{Keywords}

Internal displacement, internally displaced persons, children, African Children's Charter, Kampala Convention, Africa

* Coordinator, Global Engagement Network on Internal Displacement in Africa; fellow, Centre for Human Rights, Faculty of Law, University of Pretoria.

* Professor of law, Dullah Omar Institute for Constitutional Law, Governance and Human Rights, University of the Western Cape, South Africa; Faculty of Law, University of the Western Cape.

The views expressed in this article do not necessarily represent the views of any organization with which either author is associated.

An initial draft of this article was first presented at the Conference on the Status of Children's Rights in Africa Since the Adoption of the Charter, organized as part of the celebration of the 25th anniversary of the African Charter on the Rights and Welfare of the Child (the Charter) held in Addis Ababa, Ethiopia, November 2015. 


\section{INTRODUCTION}

Over recent decades, significant attention has focused on the need to address the gap in protection that often accompanies forced displacement. While attention has been paid to the plight of refugee children, ${ }^{1}$ an additional notable gap within the African regional context ${ }^{2}$ also relates to the protection of, and assistance for, internally displaced children (IDCs), hence the relevance of this article. The issue of internal displacement is a significant regional concern. While this situation renders all categories of persons vulnerable to hardship, some categories are often disproportionately affected due to certain factors. In the case of children, their developmental state makes them particularly vulnerable to certain risks, such as sexual exploitation, physical abuse and enforced conscription where, for instance, the civilian or humanitarian character of displacement camps is compromised. The attendant socio-economic implications of internal displacement also place children in a vulnerable state.

In recognition of the situation of IDCs, article 23(4) of the African Charter on the Rights and Welfare of the Child (African Children's Charter) ${ }^{3}$ specifically requires states to ensure protection. However, the African Children's Charter does not elaborate on the nature of the protection to be afforded. Within the context of relevant regional standards specifically relating to internal displacement and the rights of children, this article examines how IDCs can be protected in the context of article 23(4).

In advancing the discussion, the article is divided into two main parts. The first examines the impact of internal displacement on children, considering the prevalence of this issue and how children are specifically affected in situations of internal displacement. The second part considers the content of the protection of IDCs in article 23(4) of the African Children's Charter in light of relevant regional frameworks, including the African Union (AU) Convention for the Protection and Assistance of Internally Displaced Persons in Africa (Kampala Convention). ${ }^{4}$

\section{THE IMPACT OF INTERNAL DISPLACEMENT ON CHILDREN}

Displacement has a particularly devastating effect on children, not only because of their developmental stage, but also due to the socio-economic

1 For example, JM Pobjoy The Child in International Refugee Law (2017); S Arnold Children's Rights and Refugee Law: Conceptualising Children Within the Refugee Convention (2018).

2 T Kaime "The protection of refugee children under the African human rights system: Finding durable solutions in international law" in J Sloth-Nielsen (ed) Children's Rights in Africa: A Legal Perspective (2016, Routledge) 183; T Chenyika Social Work and Psychological Services for African Refugee Children: An Evaluation of the Effectiveness of Statutory Service Provision Based on a Research Study in Wales, UK (2011, Dissertation.com).

3 Adopted in Addis Ababa, Ethiopia on 11 July 1990, entered into force on 29 November 1999.

4 Adopted in Kampala, Uganda on 23 October 2009, entered into force on 6 December 2012. 
deprivations that may occur from displacement. The UN Special Representative of the Secretary-General for Children and Armed Conflict recognized that, "[d]isplacement is an especially destabilizing and traumatic experience for children as it uproots and exposes them to risks at a time in their lives when they most need protection and stability". ${ }^{5}$ Some of these risks include sexual exploitation, conscription into armed groups, trafficking, health challenges and lack of access to education. In 2019, about 19 million internally displaced persons (IDPs) were children, nearly half of the word's 46 million IDPs. ${ }^{6}$ With displacement often comes significant challenges. Over the last decade, these challenges have emerged in various contexts.

In the Central African Republic, where more than half of the 935,000 people displaced by conflicts in 2014 were children, ${ }^{7}$ IDCs in camps suffered significantly from acute malnutrition. ${ }^{8}$ The UN Children's Fund (UNICEF) representative observed that children were more likely to die of malnutrition than bullets in the country, ${ }^{9}$ due to the inabilities of families to provide for them, heightened by displacement.

At the height of the displacement crisis in Nigeria, over a million children were displaced from the northern region, both within the country and into neighbouring countries, due to the Boko Haram insurgency. ${ }^{10}$ Across camps and host communities, facilities have been significantly overstretched, exposing children to several health challenges including acute malnutrition. ${ }^{11}$ In South Sudan, nearly half of 800,000 children displaced by the conflict in

5 E Mooney and D Paul "The rights and guarantees of internally displaced children in armed conflict" (Office of the Special Representative of the Secretary-General for Children and Armed Conflict, working paper no 2, September 2010) at 11.

6 M Aydogan "Over 19m children internally displaced in 2019: UNICEF" (5 May 2020) Anadolu Agency.

7 "Insecurity pushes number of displaced in Central Africa Republic past 935,000" (3 January 2014, UN High Commissioner for Refugees); "Almost one million persons, mostly children, internally displaced in Central African Republic" (10 January 2014, European Council on Refugees and Exiles).

8 P Flynn "Displaced by violence, children in the Central African Republic face another threat: Malnutrition” (29 April 2014, UNICEF).

9 "In Central African Republic, 'more children will die from malnutrition than bullets' UN agency" (25 April 2014) UN News Centre; "Central African Republic (CAR)" (Office for the Coordination of Humanitarian Affairs, situation report no 23, 1 May 2014) at 2.

10 According to UNICEF, "nearly 1.2 million children - over half of them under 5 years old have been forced to flee their homes": "Over 1.4 million children forced to flee conflict in Nigeria and region” (18 September 2015, UNICEF).

11 UNICEF "Missing childhoods: The impact of armed conflict on children in Nigeria and beyond" (2015) at 2; "Nigeria: Humanitarian aid lacking for children at IDP camps" (18 September 2015) CCTV Africa; "Nigeria's Boko Haram crisis: Half a million 'flee in five months" (18 September 2015) BBC News (Africa); AB Oluwatosin et al "Malnutrition among internally displaced persons children: A consequence of armed conflicts in Nigeria" (2019) 7/2 Journal of Global Peace and Conflict 31. 
2015 had no access to education. ${ }^{12}$ IDCs without parents and those whose parents were unable to administer care and support were also at risk of sexual exploitation. ${ }^{13}$

In the Democratic Republic of Congo, Liberia, Uganda and Chad, the recruitment of children as soldiers in IDP camps has been prevalent. ${ }^{14}$ During the Liberian civil war, children were forcibly recruited as child soldiers both by government and militia forces. ${ }^{15}$ In Kenya, where more than 600,000 people were displaced by the post-election violence in 2007, incidences were reported of sexual exploitation of young girls displaced by the conflict. ${ }^{16}$ In Zimbabwe, where around 223,000 school-aged children were affected by an urban renewal operation carried out by the state, Fynn observes that, "[o]verall 22 per cent of displaced children dropped out [of school] because of the evictions as parents could no longer afford tuition and some children moved farther away from their schools". ${ }^{17}$

As children are heavily dependent on the functioning of social structures within families and communities, which are often disrupted by displacement, it is essential to protect them against the consequences of displacement. Although child refugees face similar concerns to IDCs, the protection of the latter may sometimes be difficult in view of the fact that they remain within the territory of the state that, in a number of cases, occasioned their displacement or failed to protect them adequately. ${ }^{18}$

\section{AN INTERPRETATION OF ARTICLE 23(4) OF THE AFRICAN CHILDREN'S CHARTER}

Over recent decades, extensive scholarly literature has emerged on the African Children's Charter and its impact in furthering the rights and welfare of the child. ${ }^{19}$

12 "Half South Sudan's 800000 displaced children not in school: Report" (4 August 2015) News 24.

13 S Foltyn "South Sudan child prostitution on the rise" (29 June 2014) Al Jazeera.

14 KE Dupuy and K Peters War and Children: A Reference Handbook (2010, Praeger) at 29; M Janmyr "Recruiting internally displaced persons in civil militias: The case of northern Uganda” (2014) 32/3 Nordic Journal of Human Rights 199.

15 Human Rights Watch "How to fight, how to kill: Child soldiers in Liberia" (2004) at 10.

16 M Wachira and C Vukets "Women in camps turn to prostitution" (29 August 2009) Daily Nation; K Migiro "Children displaced in Kenya's 2007 elections sell sex and live in tents UN” (9 May 2014) Thomas Reuters Foundation.

17 VP Fynn Legal Discrepancies: Internal Displacement of Women and Children in Africa (2010, Flowers Books) at 115.

18 The fact that IDPs remain within state borders makes their protection an imperative. Where states deny the existence of the problem or abdicate responsibility, this often heightens the vulnerability of IDPs. See OK Lwabukuna "Internal displacement in Africa: African solutions to African problems? Challenges and prospects" (2011) 1/1 Journal of Internal Displacement 132 at 139.

19 For example: F Viljoen "Supra-national human rights instruments for the protection of children in Africa: The Convention on the Rights of the Child and the African Charter on the Rights and Welfare of the Child' (1998) 31/2 Comparative and International Law Journal 
The African Children's Charter takes into account regional specificity on protecting children on the African continent. ${ }^{20}$

However, a pertinent gap in the literature on children's rights relates to the protection of IDCs, specifically within the context of article 23(4) of the African Children's Charter. This article seeks to address this gap through an interpretation of article 23(4). Article 23(4) provides that the provisions of the subparagraphs of article 23 (which apply to refugee children) shall "apply mutatis mutandis to internally displaced children whether through natural disaster, internal armed conflicts, civil strife, breakdown of economic and social order or however caused".

A starting point in interpretating treaties, as reflected in the Vienna Convention on the Law of Treaties, is to unpack the treaty in "accordance with the ordinary meaning to be given to the terms of the treaty in their context". ${ }^{21}$ Evidently, it is important to understand what the African Children Charter implies when it provides that the provisions of article 23 shall apply mutatis mutandis.

Mutatis mutandis is a Latin phrase meaning of "frequent practical occurrence, meaning that matters or things are generally the same, but to be altered, when necessary, as to names, offices, and the like". ${ }^{22}$ Scovazzi argues that, "it applies where a provision is taken from an instrument and repeated in another with some adjustments that do not change its substantive content and its scope". ${ }^{23}$ In understanding this phrase, a starting point is to consider the regimes governing the protection of refugee children and IDCs. It is crucial to mention that both categories are covered by separate legal regimes. While refugee children are covered by the UN 1951 Refugee Convention, its 1967 Protocol and the 1969 Organisation of African Unity (OAU) Refugee

contd

of Southern Africa 199; A Lloyd "A theoretical analysis of the reality of children's rights in Africa: An introduction to the African Charter on the Rights and Welfare of the Child" (2002) 2 African Human Rights Law Journal 11; DM Chirwa "The merits and demerits of the African Charter on the Rights and Welfare of the Child" (2002) 10/2 The International Journal of Children's Rights 157; D Olowu "Protecting children's rights in Africa: A critique of the African Charter on the Rights and Welfare of the Child" (2002) 10 International Journal of Children's Rights 127; J Sloth-Nielsen and BD Mezmur "Surveying the research landscape to promote children's legal rights in an African context” (2007) 7/2 African Human Rights Law Journal 330; T Kaime The African Charter on the Rights and Welfare of the Child: A Socio-Legal Perspective (2009).

20 UNICEF "Review of progress in the advancement of child rights in Africa: Reflecting on the past and future challenges and opportunities" (report submitted to the UNICEF Office to the AU and UN Economic Commission for Africa and UNICEF Evaluation Office, 2020).

21 Vienna Convention on the Law of Treaties (1969), art 31(1).

22 "Mutatis mutandis" Law Dictionary, available at: <https://dictionary.thelaw.com/mutatismutandis/> (last accessed 21 December 2020).

23 T Scovazzi "Within and beyond mutatis mutandis" in M Ragazzi Responsibility of International Organizations: Essays in Memory of Sir Ian Brownlie (2013, Martinus Nijhoff) 121 at 121 . 
Convention (OAU Refugee Convention), ${ }^{24}$ the normative frameworks on the protection of IDCs are the 1998 UN Guiding Principles on Internal Displacement (UNGP) and the Kampala Convention. It is important to emphasize that there is a complementary relationship between these frameworks and this relates to the fact that they each encompass forcibly displaced populations. However, the framework on refugee law is applicable to instances where children have crossed an internationally recognized state border and are seeking international protection in another state. In this context, the national regime on refugee protection in the state of displacement will apply, along with international and regional refugee law frameworks. However, integral to international protection for refugees is the definition of "refugee". The OAU Refugee Convention reflects the international and regional definitions, providing in article 1 :

“(1) The term 'refugee' shall mean every person who, owing to well-founded fear of being persecuted for reasons of race, religion, nationality, membership of a particular social group or political opinion, is outside the country of his nationality and is unable or, owing to such fear, is unwilling to avail himself of the protection of that country, or who, not having a nationality and being outside the country of his former habitual residence as a result of such events is unable or, owing to such fear, is unwilling to return to it.

(2) The term 'refugee' shall also apply to every person who, owing to external aggression, occupation, foreign domination or events seriously disturbing public order in either part or the whole of his country of origin or nationality, is compelled to leave his place of habitual residence in order to seek refuge in another place outside his country of origin or nationality."

Meeting this definition is integral to acquiring refugee status, which is granted upon the procedure of status determination. On the other hand, being an IDP is not status-dependent and consequently not subject to status determination. A child becomes an IDP where he or she has been: "forced or obliged to flee or to leave their [home] or [place] of habitual residence, in particular as a result of or in order to avoid the effects of armed conflict, situations of generalized violence, violations of human rights or natural or human-made disasters, and who [has] not crossed an internationally recognized State border". ${ }^{25}$

However, it is important to emphasize that both refugee children and IDCs are accorded the same rights under the African Children's Charter. With respect to refugee children, states of asylum have a fundamental duty not to return refugee children to a country where there is a well-founded fear of

24 UN Convention Relating to the Status of Refugees (1951); Protocol Relating to the Status of Refugees (1967); OAU Convention Governing the Specific Aspects of Refugee Problems in Africa (1969).

UNGP, para 2; Kampala Convention, art 1(k). 
persecution or where there is "external aggression, occupation, foreign domination or events seriously disturbing public order". ${ }^{26}$ The principle of nonrefoulement ${ }^{27}$ relates to both direct and indirect forms of return. An indirect form of return, for instance, could be non-compliance with human rights frameworks, including the African Children's Charter. According to Khan, "there is a direct link between the withholding of rights - socio-economic, administrative or civil and political rights - from refugees and their failure to integrate locally". ${ }^{28}$ Withholding charter-based protection could be an indirect form of refoulment, which is prohibited under refugee law.

Protection from arbitrary displacement is cardinal to IDP protection. Protection from arbitrary displacement requires that the root cause of internal displacement must not be permissible under international law. Permissible forms of internal displacement include those that are occasioned by development projects, armed conflict or natural disasters. ${ }^{29}$ However, displacement must also be in accordance with due process requirements, which are specific to the root cause of internal displacement, generally reflected in the law on internal displacement and also those requirements that are group-based. The African Children's Charter is specifically relevant in respect of IDCs.

In addition to charter-based protection, IDC protection must also be construed with reference to the normative regime on internal displacement, specifically the Kampala Convention. Hence, the protection of IDCs mutatis mutandis is two-pronged. It requires that protection should be read in light of both the African Children's Charter and the Kampala Convention, which specifically relates to internal displacement.

The provisions of article 23 of the African Children's Charter, specifically paragraphs (1)-(3), may be read mutatis mutandis (ie with necessary adjustments, specific to IDCs), as follows:

“(1) State Parties to the present Charter shall take all appropriate measures to ensure that an [internally displaced] child ... shall, whether unaccompanied or accompanied by parents, legal guardians or close relatives, receive appropriate protection and humanitarian assistance in the enjoyment of the rights set out in this Charter and other international human rights and humanitarian instruments to which the States are Parties.

(2) State Parties shall undertake to cooperate with existing international organizations which protect and assist [an internally displaced child] in their efforts to protect and assist such a child and to trace the parents or other close relatives of an unaccompanied [internally displaced] child in order to obtain information necessary for reunification with the family.

26 OAU Refugee Convention, art 1(2).

27 This principle prohibits states from returning refugees or asylum-seekers to territories where there is a risk that their life or freedom would be threatened.

28 F Khan "The principle of non-refoulement" in F Khan and T Schreier Refugee Law in South Africa (2014, Juta \& Co Ltd) 3 at 12.

29 See Kampala Convention, art 4(4). 
(3) Where no parents, legal guardians or close relatives can be found, the child shall be accorded the same protection as any other child permanently or temporarily deprived of his family environment for any reason."

While article 23(1) of the African Children's Charter emphasizes the need to take "appropriate measures" for the protection of IDCs, it is not clear what such measures entail. To understand the term, however, it is relevant to consider a similar phrase used in the International Covenant on Economic, Social and Cultural Rights: "appropriate means"..$^{30}$ In General Comment No 3, the UN Committee on Economic, Social and Cultural Rights (ESCR Committee) emphasized that the phrase "appropriate means" must be accorded its "full and natural meaning". ${ }^{31}$ Taking the ordinary meaning rule, the term "appropriate" means "suitable" or what is "proper in [given] circumstances". ${ }^{32}$ Although the ordinary definition affords semantic clarification, placed within the context of the obligation in article 23(1) of the African Children's Charter, it is unclear what such measures entail. The ESCR Committee, however, highlights that such measures should include legislative, administrative, financial, educational, judicial and social measures. ${ }^{33}$ Although states have a margin of discretion in determining what is appropriate, the ESCR Committee iterated that the "ultimate determination as to whether all appropriate measures have been taken remains one for the [ESCR] Committee to make". ${ }^{34}$ In relation to the right of the child to freedom from all forms of violence, in General Comment No 13, the Committee on the Rights of the Child described the phrase "appropriate measures" as requiring the adoption of a "broad range of measures cutting across all sectors of Government, which must be used and be effective in order to prevent and respond to all forms of violence". ${ }^{35}$

Placing these descriptions within the context of article 23 of the African Children's Charter, the obligation of the state to "take all appropriate measures" requires states to take a wide range of measures, not least, legislative, administrative, financial, educational, judicial and social measures that respond effectively to the protection of IDCs. In line with article 23(1), this wide range of measures should be geared towards "appropriate protection and humanitarian assistance" for the enjoyment of the rights in the African Children's Charter and other international instruments. Although article 23 does not define what "appropriate protection and humanitarian assistance"

30 International Covenant on Economic, Social and Cultural Rights (1966) 993 UNTS 3, art 2(1).

31 General Comment No 3 on Article 2(1): The Nature of State Parties' Obligation, UN doc E/1991/23 (14 December 1990), para 4.

32 "Appropriate" in Oxford English Dictionary (2015, Oxford).

33 General Comment No 3, above at note 31, paras 4, 5 and 7.

34 Id, para 4.

35 General Comment No 13: The Right of the Child to Freedom from all Forms of Violence, UN doc CRC/C/GC/13 (18 April 2011), para 39. See also R Stere "Human rights and drug control: The importance of children's rights" in S Takahashi (ed) Human Rights, Human Security, and State Security: The Intersection (2014, Praeger) 145 at 151-52. 
should entail, it immediately refers to the African Children's Charter and other international instruments as sources of guidance. In order to ensure "appropriate protection and humanitarian assistance" in line with the African Children's Charter, the provisions of the charter that respond to the risks that IDCs are likely to encounter are imperative. These provisions include survival and development, ${ }^{36}$ education, ${ }^{37}$ health and health services, ${ }^{38}$ protection against child abuse and torture, ${ }^{39}$ armed conflicts, ${ }^{40}$ separation from parents, ${ }^{41}$ sexual exploitation, ${ }^{42}$ and sale, trafficking and abduction. ${ }^{43}$

Moreover, in understanding "appropriate protection and humanitarian assistance" in the context of other international instruments and specifically also with reference to IDCs, a pertinent reference point within the regional context is the Kampala Convention. As the regional framework on internal displacement, the Kampala Convention is the specific law on IDP issues and must be referred to in order to understand the corpus of protection and assistance for IDPs. However, an important question relates to whether utilizing the Kampala Convention places extra responsibility on states that are not party to that convention, but are parties to the African Children's Charter. In answering this question, it is relevant to reflect on article 46 of the African Children's Charter, which provides that inspiration may be drawn from:

"International Law on Human Rights, particularly from the provisions of the African Charter on Human and Peoples' Rights, the Charter of the Organization of African Unity, the Universal Declaration on Human Rights, the International Convention on the Rights of the Child, and other instruments adopted by the United Nations and by African countries in the field of human rights, and from African values and traditions."

In light of this provision, inspiration may be drawn from other regional instruments in furthering the interpretation of obligations in the African Children's Charter. Evidently, in relation to internal displacement, the Kampala Convention is an imperative instrument. Significant literature on the Kampala Convention reinforces its value as the regional normative corpus on internal displacement, articulating standards on IDP treatment. ${ }^{44}$ The

36 African Children's Charter, art 5.

37 Id, art 11.

38 Id, art 14.

39 Id, art 16.

40 Id, art 22.

41 Id, art 25.

42 Id, art 27.

43 Id, art 29.

44 For example: P Kamungi "Beyond good intentions: Implementing the Kampala Convention" (2010) 34 Forced Migration Review 53; M Stavropoulou "The Kampala Convention and protection from arbitrary displacement" (2010) 36 Forced Migration Review 62; S Ojeda "The Kampala Convention on Internally Displaced Persons: Some 
Kampala Convention is a 23-article instrument that significantly reinforces the need for states to protect and assist IDPs. Adopted in 2009 at the Special Summit of AU Heads of States and Government in Uganda, the Kampala Convention has gained significant attention, having shaped the regional IDP landscape. Over the last decade, the Kampala Convention has been ratified by more than half the AU member states. An important provision of the Kampala Convention is its emphasis on the right not to be arbitrarily displaced, which is integral to the narrative of protecting and assisting IDPs. Embedded in this narrative is the need for protection across a continuum: from preventing displacement to ensuring that durable solutions are provided for IDPs.

While reinforcing a complementary link with the African Children's Charter, there are specific provisions incorporated in the Kampala Convention for the protection of IDCs. For instance, the Kampala Convention reinforces the need for states to ensure that children are not recruited or allowed to take part in hostilities "under any circumstances". ${ }^{45}$ Moreover, there must not be forcible recruitment of children. ${ }^{46}$ The Kampala Convention also prohibits "kidnapping, abduction or hostage taking ... sexual slavery and trafficking in persons especially women and children". 47 The Kampala Convention further accentuates the need for "special protection" for unaccompanied children. ${ }^{48}$ This is particularly relevant given the fact that displacement often creates a situation where children may be separated from their parents or guardians. Evidently in such contexts, article 23(2) and (3) of the African Children's Charter reinforces specific measures that states must take into account, particularly the need to cooperate with international organizations that protect and assist IDCs to ensure family tracing and reunification. The Kampala Convention specifically requires states to establish "specialized mechanisms" for family tracing and reunification. ${ }^{49}$

contd

international humanitarian law aspects" (2010) 29/3 Refugee Survey Quarterly 58; L Groth "Engendering protection: An analysis of the 2009 Kampala Convention and its provision for internally displaced women” (2011) 23/2 International Journal of Refugee Law 221; FZ Guistiniani "New hopes and challenges for the protection of IDPs in Africa: The Kampala Convention for the Protection and Assistance of Internally Displaced Persons in Africa" (2011) 39/2 Denver Journal of International Law and Policy 347; K Ridderbos "The Kampala Convention and obligations of armed groups" (2011) 37 Forced Migration Review 36; MT Maru The Kampala Convention and Its Contribution to International Law: Legal Analyses and Interpretations of the African Union Convention for the Protection and Assistance of Internally Displaced Persons (2014, Eleven Publishing); AM Abebe The Emerging Law on Forced Migration in Africa: Development and Implementation of the Kampala Convention on Internal Displacement (2016, Routledge).

45 Kampala Convention, art 7(e).

46 Id, art $9(1)(d)$.

47 Id, art $7(\mathrm{f})$.

48 Id, art 9(2)(c).

49 Id, art 9(2)(h) 
Such mechanisms may be established within the frame of cooperation with these organizations.

The Kampala Convention is also emphatic regarding the need to ensure that humanitarian assistance will "include food, water, shelter, medical care and other health services, sanitation, education, and any other necessary social services". ${ }^{50}$ Moreover, it requires states to "assess or facilitate the assessment of the needs and vulnerabilities of internally displaced persons and of host communities, in cooperation with international organizations or agencies". ${ }^{51}$ One emphasis of this provision is the need for states to adopt a child-based assessment standard, leveraging the rights-based frameworks. This assessment should take into account the peculiarity of the given context. Where technical capacity is required, it is imperative to leverage international cooperation, particularly from agencies and organizations involved in the provision of humanitarian assistance at various levels of governance.

Notably, in taking a child-based assessment, it is imperative to be guided by the cardinal principles regarding children's rights: the best interests of the child, non-discrimination and participation. Adopting a best interest lens in interpreting the obligations in the Kampala Convention requires that states should be guided by the need to integrate child protection into the development of humanitarian response plans. An important area in which this has emerged as an imperative is in the context of education. Wanjiru observes with respect to Kenya, for instance, that "recurring political-instigated violence has resulted in displacement of many families and disrupting access and participation in education for many affected children". ${ }^{52}$ At the height of the IDP crisis in Nigeria in 2015 , for instance, "19 out of the 42 camps did not have access to any form of education". ${ }^{53}$ Given the prevalent insecurity in the northeast region of Nigeria due to the Boko Haram conflict, and where there is a significant proportion of IDCs, the introduction of the Safe Schools Initiative is a pertinent step in the right direction. While there has been some progress, ${ }^{54}$ the implementation of this initiative has been affected by concerns

50 Id, art 9(2)(b).

51 Id, art 5(5).

52 J Wanjiru "Inclusive education for internally displaced children in Kenya: Children's perceptions of their learning and development needs in post-conflict schooling" (2018) 12/7 International Journal of Child Care and Education Policy 1 at 3.

53 "No more excuses: Provide education to all forcibly displaced people" Education Cannot Wait, available at: <https://www.educationcannotwait.org/no-more-excuses-provideeducation-to-all-forcibly-displaced-people/> (last accessed 21 December 2020).

54 For instance, under this initiative the government "successfully transferred around 2,274 out of 2,400 internally displaced children from Adamawa, Borno and Yobe to 43 Federal Government Colleges": Federal Republic of Nigeria "Nigeria's response to questions raised by the AU Committee on the Rights and Welfare of the Child on the second and third periodic state party reports submitted by Nigeria on the status of the implementation of the African Charter on the Rights and Welfare of the Child (ACRWC) and the enjoyment of these rights in the Federal Republic of Nigeria" (2019) (copy on file with the authors). 
over mismanagement. ${ }^{55}$ Fostering best interests requires that there is adequate oversight of the implementation of initiatives for the protection of IDPs, including children.

The principle of non-discrimination must also be respected in furthering protection and assistance for IDCs. An area where this principle is particularly relevant is in the protection of IDCs in urban areas, particularly where protection is not extended to IDPs within such contexts. This was a challenge in Uganda, for instance. IDPs outside camps were not being registered; as such, ration cards were distributed to IDPs in camps, ${ }^{56}$ but "not to displaced children in non-camp, urban settings". ${ }^{57}$ In a 2019 report, UNICEF observed:

"Internally displaced children in urban settings face significant challenges in accessing services without registration and documentation. In displacement camps, registration of displaced people is often the only requirement for accessing aid and services. But in cities, access to services generally requires personal identification papers. Without these, children and their families may be unable to enrol in school, or to receive healthcare, humanitarian aid and secure housing. This makes the loss of personal identification documents, and challenges replacing them, a recurring issue for all IDPs, especially problematic for children in urban areas." 58

Moreover, states must be guided by the need to ensure that children participate in the processes of IDP protection and assistance. This is often a challenge, especially because of the pre-existing socio-cultural contexts in which displacement occurs. Where there are no adequate strategies for child participation in decision-making processes, particularly in considering alternative strategies to development projects, IDCs may be excluded. The Kampala Convention reinforces the need for states to "consult internally displaced persons and allow them to participate in decisions relating to their protection and assistance". ${ }^{59}$ Developing child-friendly participatory processes is integral to this endeavour.

However, central to the application of article 23 of the African Children's Charter is the determination of the age of a child. While much discussion has gone into this subject within the context of refugee law, less has been said on this issue in the context of internal displacement. However, in a situation of internal displacement where individuals are uprooted from their homes and places of habitual residence, age assessment concerns may arise, for instance in a situation where families are separated or there are no

55 C Oduah "Nigerians ask how millions for safe schools program are being spent" (28 May 2018) Voice of America.

56 H Refstie, C Dolan and MC Okello "Urban IDPs in Uganda: Victims of institutional convenience' (2010) 34 Forced Migration Review 33.

57 UNICEF "Protecting and supporting internally displaced children in urban settings" (2019) at 7.

58 Ibid.

59 Kampala Convention, art 9(2)(k). 
documents to prove the age of a particular child. In the context of refugee children, where significant guidance has emerged, there is an emphasis on a principled approach in line with established technical guidance from UNICEF. ${ }^{60}$ The technical guidance sets out specific prescriptions in assessing the age of a child. ${ }^{61}$ Overall, there is an emphasis on the need to balance age assessments with the best interests of the child. Consequently, this should only be done "when it can clearly be demonstrated that the decision to do so has been based solely on the best interests of the child". ${ }^{62}$ In view of the fact that such assessments should only be a last resort, the age given by the child should be "a starting point and normally be relied upon unless blatantly incorrect". ${ }^{63}$ However, such an assessment must be carried out without discrimination. This requires that "preconceived ideas that certain categories of children give misleading information about their age" must be dispensed with. ${ }^{64}$ Further, the informed consent of the child is crucial to this process as an imperative precondition. Children must also be allowed to consult with parents and / or guardians for support in the process. Moreover, the age assessment process "must follow the least intrusive method which is sensitive to the individual's gender and culture and maintains the individual's dignity and physical integrity at all times". ${ }^{65}$ In addition, any "margin of error" must be construed in a child's favour. Such assessment should adopt a "holistic approach" and, as such, take into account a wide range of issues, including "physical, psychological, developmental, environmental and cultural factors". ${ }^{66}$ Further, information regarding the assessment must be provided. A right of appeal against an assessment must also be accorded. Overall, the assessment must be carried out by skilled and independent practitioners. With respect to IDCs, a flexible approach is required, given that being an IDP is not a "legal" status. As such, there should be less emphasis on age assessment and more emphasis on protecting the best interests of the child. As a general rule, the age given by the child should be used; where no conclusive evidence is presented to prove a young person's age, childhood should be presumed. More importantly, however, it is crucial that the general protection measures adopted by states are child-friendly.

\section{CLARIFYING INTERPRETATION}

Having examined the obligations in article 23(4) of the African Children's Charter, a relevant question is how clarity on this obligation should be

60 UN Refugee Agency "Guidelines on assessing and determining the best interest of the child” (2018) at 54-55.

61 UNICEF “Age assessment: Technical note” (2013).

62 Ibid.

63 Ibid.

64 Ibid.

65 Ibid.

66 Ibid. 
advanced at the regional level. This article specifically argues for the development by the African Committee of Experts on the Rights and Welfare of the Child (ACERWC) of a general comment on article 23(4). Evidently, the inclusion of the protection of IDCs in the African Children's Charter is significant, also given that this is not specifically included in the Convention on the Rights of the Child. However, for a proper interpretation of this provision, it is important that there is clarity. What clarity implies is that states have sufficient guidance in order to implement the provisions of a treaty. In this context, the role of the ACERWC is relevant given its mandate under article 42 of the African Children's Charter to develop guidance in the furtherance of treaty provisions.

General comments are generally interpretative guidance that are relevant for a clear and substantive understanding of treaty provisions. ${ }^{67}$ They are soft law norms and standards that have assumed importance in elaborating on guidance in the furtherance of treaties by human rights institutions at various levels of governance, in particular at the global and African regional level. The ACERWC has utilized this interpretative guide in expounding on specific obligations in the African Children's Charter. For instance, through general comments, the ACERWC has expounded on a child's right to a name and nationality under article 6,68 rights of children of imprisoned mothers under article $30^{69}$ and the responsibility of the child under article $31 .^{70} \mathrm{~A}$ general comment on article 23(4) of the African Children's Charter would be useful in understanding what is required from states in the furtherance of the treaty provisions. However, in developing such a general comment, it is imperative that the ACERWC ensures that a background study is conducted to map the general state of protection and assistance to IDCs in Africa. Such a study would be useful for generating knowledge and also for advocacy with AU member states on the pertinence of applying this common standard in furthering sustainable solutions to IDCs. This study could be jointly developed with the African Commission on Human and Peoples' Rights and launched at a meeting of the Conference of State Parties to the Kampala Convention.

\section{CONCLUSION}

As of December 2020, 50 states had ratified the African Children's Charter, which is nearly all $\mathrm{AU}$ member states. ${ }^{71}$ Furthermore, the legislation of at

67 I Bantekas and L Oette International Human Rights Law and Practice (3rd ed, 2020, Cambridge University Press).

68 General Comment on Article 6 of the African Charter on the Rights and Welfare of the Child: Right to Birth Registration, Name and Nationality: ACERWC/GC/02 (2014).

69 General Comment on Article 30 of the African Charter on the Rights and Welfare of the Child: Children of Incarcerated and Imprisoned Parents and Primary Caregivers: ACERWC/GC/01 (2013).

70 General Comment on Article 31 of the African Charter on the Rights and Welfare of the Child on the Responsibilities of the Child (2017).

71 Algeria, Angola, Benin, Botswana, Burkina Faso, Burundi, Cameroon, Cape Verde, Central African Republic, Chad, Comoros, Congo Brazzaville, Côte d'Ivoire, Democratic 
least two African countries (Liberia and Nigeria) includes explicit protection for IDCs. ${ }^{72}$ Protecting IDCs is imperative, given the evident reality on the continent and increasing episodes of internal displacement. Yet, very limited knowledge exists on their protection and assistance in the literature. This is an evident gap that this article has attempted to address through the optics of article 23(4) of the African Children's Charter. While this article advances an interpretation of this provision and, indeed, emphasizes the role of the ACERWC in providing clarity through the exposition of interpretive guidance, it is crucial to emphasize that much of the relevance of this provision will largely depend on its implementation within national contexts. As such, beyond developing norms, it is important that states reflect these norms further, through practical steps towards implementation. In this regard, the ACERWC needs to employ follow-up mechanisms in the furtherance of protecting and assisting IDCs, particularly through missions to AU member states with significant IDC populations, reinforcing the pertinence of compliance with the protection of IDCs under article 23(4) of the African Children's Charter.

\section{CONFLICTS OF INTEREST}

None

contd

Republic of Congo, Djibouti, Egypt, Equatorial Guinea, Eritrea, Eswatini, Ethiopia, Gabon, Gambia, Ghana, Guinea, Guinea-Bissau, Kenya, Lesotho, Liberia, Libya, Madagascar, Malawi, Mali, Mauritania, Mauritius, Mozambique, Namibia, Niger, Nigeria, Rwanda, São Tomé and Príncipe, Senegal, Seychelles, Sierra Leone, South Africa, Sudan, Tanzania, Togo, Uganda, Zambia and Zimbabwe: "List of countries which have signed, ratified / acceded to the African Charter on the Rights and Welfare of the Child", available at: <https://www.acerwc.africa/ratifications-table/> (last accessed 21 December 2020).

72 Liberia Children's Law (2011), art 5(1); Nigeria's Child Rights Act No 26 (2003), art 171(10) (a)(iii). 